\title{
A New Rule for Monetary Policy
}

\author{
Tony Makin
}

D

ISAGREFMENTS about the conduct of monetary policy have traditionally centred on the relative importance of its goals and the best means of achieving them. Today, central bankers everywhere treat inflation control as the main objective of monetary policy, but retain considerable discretionary powers while operating with varying degrees of independence from governments. But do central banks know more about an economy's fundamentals than the financial markets, which act, directly or indirectly, on behalf of all agents in the economy?

Under present arrangements, the interest rate structure reflects the markets' best estimate of where the central bank will set cash rates. Interest rates vary considerably in response to the markets' continuous second guessing of discretionary changes. Discretionary interest-rate setting by the central bank thus contributes to longer-term interest rates being persistently higher than necessary, with adverse consequences for investment and long-term economic growth. If monetary policy were to become rulebased, however, market uncertainty about the future direction of the cash rate would be eliminated, and long-term interest rates would be lower than otherwise.

In this article, a new rule for monetary policy is outlined, involving the automatic setting of interest rates by the central bank. The proposed rule is based on a reinterpretation of the so-called expectations hypothesis of the term structure of interest rates. Its rationale is to minimise the level of discretion-induced economic uncertainty by effectively allowing financial markets to set all interest rates. Over time, the cash rate automatically set by the authorities in accordance with the rule would reflect, not the central bank's own discretionary view of its appropriate level, but the collective view of the financial markets based on their information set of the economy's fundamentals.

\section{Current Operating Procedures for Monetary Policy}

The modus operandi of monetary policy differs markedly across countries, both in terms of the intermediate variables targeted and with respect to the frequency and magnitude of central bank interventions to influence monetary conditions. Instead of attempting to control the money supply, as prescribed by monetarism, central banks now generally operate on one or both of the key monetary price variables: exchange rates and interest rates.

Tony Makin is Associate Professor in Economics at The University of Queensland. 
Since Australia's exchange rate was floated, the Reserve Bank alters the stance of monetary policy by focusing on interest rates through the so-called cash rate. The cash rate is set for the purpose of influencing other interest rates, particularly longer-term rates. Thus, the linkage between short- and long-term interest rates plays a major role in the transmission of changes in the stance of monetary policy to the real economy.

Changes in interest rates are thought to have an impact on the spending patterns of households and firms through liquidity, wealth, exchange rate and expectations channels. For instance, higher interest rates can curb firms' investment expenditure (as witnessed in Australia during the last great policy induced recession of the early 1990s) because the cost of capital rises relative to its productivity. Higher interest rates are also likely to reduce equity values, as investors switch from shares to bonds, thus lowering the market value of firms' capital relative to its replacement cost. According to standard theory, this further weakens the incentive for firms to invest.

Moreover, to the extent that lower equity values depress aggregate household wealth, consumption spending may also be reduced. For monetary policy to operate effectively along these lines, it is important that interest rates at the short end of the spectrum influence rates at the long end, since investment spending in particular is likely to be more sensitive to longer-term interest rate movements, given business planning horizons. The interrelationship between monetary policy, interest rates and the economy is shown schematically in Figure 1.

\section{Figure 1: Monetary policy, interest rates and the economy}

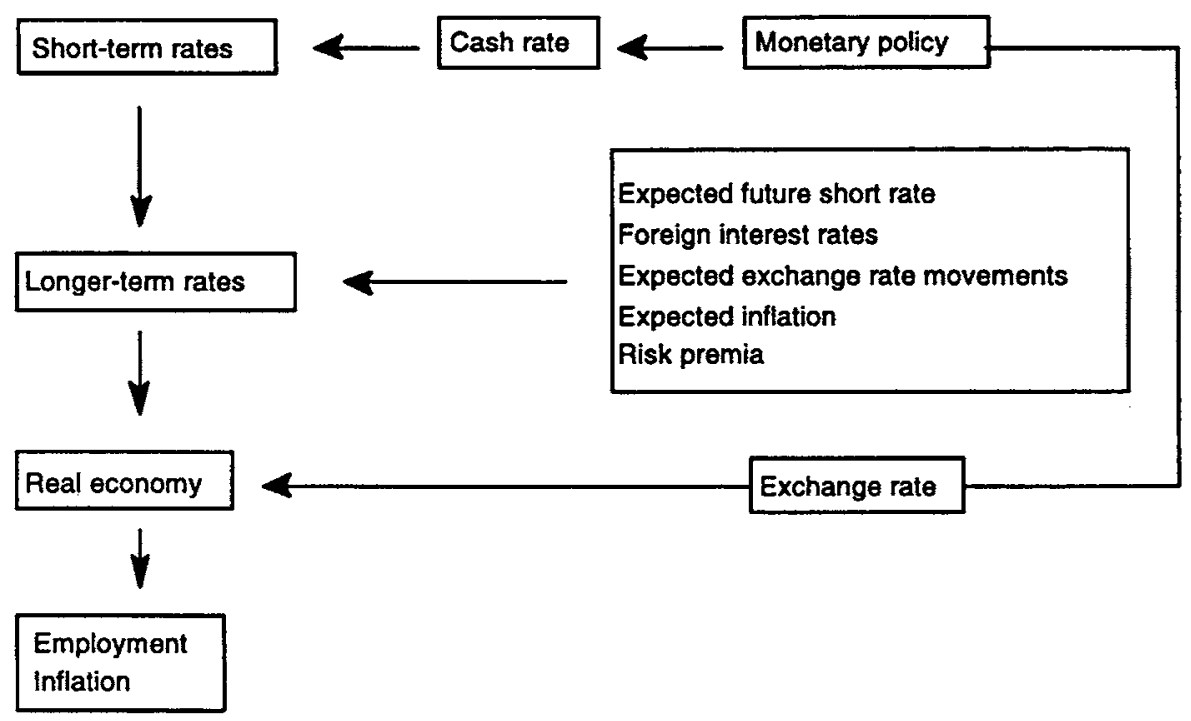

\footnotetext{
'Stevens (1996) elaborates on the Reserve Bank's view of the transmission mechanism of monetary policy.
} 
The behaviour of the targeted cash market rate, and of indicative short-term and long-term interest rates over recent years, is depicted in Figure 2. What is evident is the close relationship between the cash rate and short-term (such as the 90-day bank bill) rates. There is also evidence of substantial co-movement between short-term and long-term rates, though long-term rates have been persistently higher.

International arbitrage ties long-term rates to foreign long-term rates, with any difference between domestic and foreign interest rates likely to arise from the markets' expectation of future exchange rate changes according to the standard uncovered interest parity condition. For instance, the gaps between similar long term rates in Australia and overseas rates can reflect market expectations of future exchange rate movements, as well as liquidity and risk premia which vary over time.

\section{Figure 2: Short-term and long-term interest rates in Australia, November 1993-April 1997}

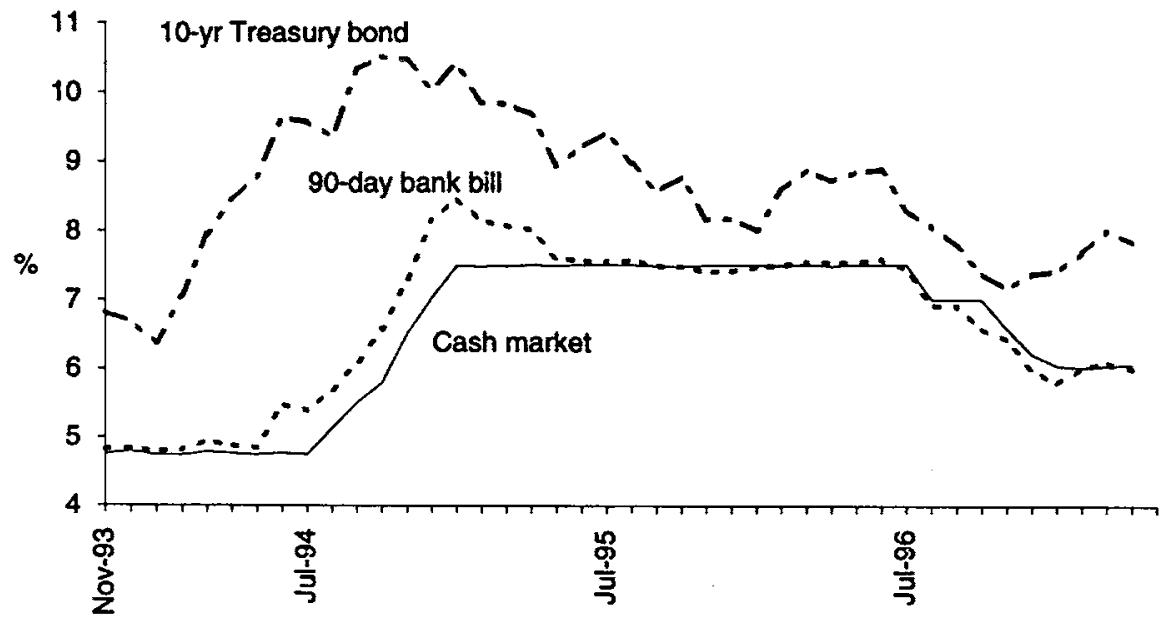

Source: Reserve Bank of Australia Bulletin (various issues, 1997).

\section{Monetary Policy and the Yield Curve}

At any given time, the so-called yield curve describes interest rates on securities which are ostensibly the same except for their terms to maturity. For instance, an ascending, or positive, yield curve shows that, for any given time interval, short-term rates on, say, five-week Treasury Notes are lower than on longer-term rates on, say, 26-week Treasury Notes. Descending or inverse yield curves convey the opposite (Figure 3). They can also be flat or hump-backed and the slope and position of the yield curve can vary from period to period. 
The yield curve itself can be used as an indicator of expected macroeconomic conditions, particularly when comparing short-run interest rates and rates at the long end of the spectrum. For instance, long-term rates will reflect expectations of the inflationary effect of current monetary policy. There will therefore be some offset to the linkage between long-term rates and officially set short-term rates to the extent that a deflationary monetary policy which raises short-term rates also lowers the markets' expectation of future inflation. The longer the maturity structure, the more important this offset is likely to be.

\section{Figure 3: Yield curves for Treasury Notes, March 1997 and April 1997}

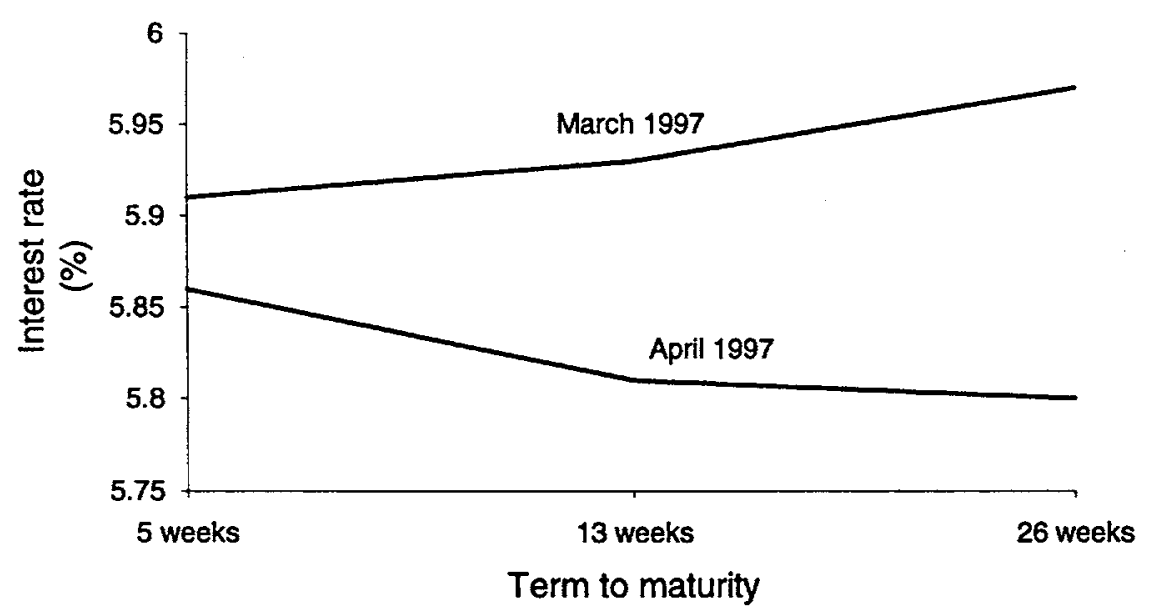

Source: Reserve Bank of Australia Bulletin, July 1997, Table F1, S45.

Various theories have been expounded over the years to explain why short-term and long-term market interest rates differ. The three main explanations of the term structure of interest rates that have been advanced are: the expectations theory; the risk (or liquidity preference) approach; and the segmented markets theory. Of these, the expectations theory is the most widely accepted. It presumes that investors regard default-free securities, like Treasury Notes, which are issued by the same entity but which differ with respect to their terms to maturity, as perfect substitutes. Accordingly, the interest rate paid on the longer-term security - say, a hypothetical 60 day Treasury Note - equals the average of the current rate on a hypothetical 30 day Treasury Note and the markets' expectations of the rate to be paid on 30 day Treasury Notes in a month's time.

In formula terms, the expectations hypothesis suggests that:

${ }^{2}$ Cox et al. (1985), Culbertson (1957), Fisher (1896), Hicks (1939), Malkiel (1986), Melino (1988) and Roll (1970) provide expositions of theories of the term structure. 
60 day rate $=0.5$ ( 30 day rate + next month's expected 30 day rate $)$

Or, more generally, $i_{2 t}=\frac{i_{t}^{s}+i_{i}^{e}}{2}$

where $i_{2 t}$ is the longer term rate, $i_{\mathfrak{t}}^{s}$ is the current, or spot, short term rate and $i_{\mathfrak{t}}^{e}$ is the short term rate expected in the next period.

For example: if the spot interest rate on a 30-day Treasury Note is 5 per cent and the market expects that the interest rate on a 30-day Treasury Note next month to be 7 per cent, then, according to this theory, the spot interest rate on a 60-day Note would be 6 per cent. It follows that an ascending yield curve depicting the short rate at 5 per cent and the long rate at 6 per cent contains information about the money market's expectation of the future short-term rate. In other words, this approach suggests that it is market opinion about future short-term rates which drives longer-term rates. The accepted corollary for monetary policy is that long-term interest rates can be changed by fixing the official short-term rate for sustained periods, since money and bond markets will base their expectations of future short-term rates on the current official rate.

The risk (or liquidity preference) theory of the term structure is effectively an augmented version of the expectations hypothesis. It suggests that investors consider short-term securities to be more attractive than longer-term bonds due to uncertainty about future short-term rates and that, accordingly, a premium is required on longerterm securities to make them as attractive to investors as short-term securities. The longer the maturity, it is argued, the higher this premium will be.

The segmented markets theory of the term structure is diametrically opposed to the expectations theory because it presumes that securities of different maturities issued by the same entity are completely non-substitutable. Accordingly, the slope of the yield curve results from the interaction of the demand and supply of securities in distinct, or separate, markets. In other words, no linkage exists between officially controlled short-term interest rates and longer-term rates.

The corollary for monetary policy here is that targeting short-term rates is largely ineffective in influencing long-rate-sensitive investment spending and macroeconomic activity. Instead, the theory implies that central banks should intervene in longer-term securities markets in order directly to influence long-term interest rates. However, this approach has few supporters and little empirical support.

\section{Using Market Expectations to Set Interest Rates}

Previous studies of the relationship between monetary policy and the yield curve have either focused on the yield curve itself as an indicator of future inflation and macroeconomic activity, or have empirically tested the validity of the expectations hypothesis

\footnotetext{
${ }^{3}$ Empirical studies by Fuhrer (1996), Tease (1988) and McFadyen et al. (1991) support the expectations hypothesis.

${ }^{4}$ An exception is Taylor (1992).
} 
to establish whether discretionary monetary policy can in practice influence longerterm interest rates.

It is proposed here that the central bank regularly set the cash rate according to a rule which is based on the expectations hypothesis and uses information contained in the yield curve itself. The procedure whereby the cash rate is inferred from the yield curve can be illustrated by reference to the hypothetical data in Table 1.

Table 1: The rule illustrated

\begin{tabular}{|c|c|c|c|}
\hline & $\begin{array}{c}(1) \\
\text { Short-term rate } \\
\left(i_{t}^{s}\right) \text { (e.g. } 30 \text {-day } \\
\text { security) }\end{array}$ & $\begin{array}{c}(2) \\
\text { Longer rate } \\
\left(\mathrm{i}_{2 t}^{\mathrm{s}}\right)(\mathrm{e.g} \cdot 60 \text {-day } \\
\text { security) }\end{array}$ & $\begin{array}{c}(3) \\
\text { Expected } \\
\text { future rate }\left(\mathrm{i}_{\mathrm{t}}^{\mathrm{e}}\right)\end{array}$ \\
\hline First period & 7.0 & 6.0 & -5.0 \\
\hline Second period & $5.0 \leftarrow$ & 6.0 & -7.0 \\
\hline Third period & $7.0 \leftarrow$ & 6.5 & 6.0 \\
\hline
\end{tabular}

The cash rate which the central bank sets by intervening in the money market is fixed at the same level as the short-term market rate shown in the first column. The second column records a relatively longer rate which reflects the market's expectation of the future cash and short-term rates. For instance, if the cash rate is 5 per cent and the longer rate is observed to be 6 per cent, it follows from the expectations hypothesis of the term structure outlined above that the markets expect the future cash rate will be 7 per cent. That is, from the earlier equation summarising the expectations hypothesis, the expected future short-term rate is simply related to the current short-term rate and the longer rate in the following way:

$$
i_{t}^{e}=\left(2 \times i_{2 t}^{s}\right)-i_{t}^{s}
$$

In this particular example, the cash rate can be automatically reset by the central bank every 30 days. Yet it would also be possible for the central bank automatically to peg the cash rate more frequently, for instance as regularly as every day, using a moving average of implicit expected rates, calculated using a designated security, such as Treasury Notes. The money and bond markets could then express their collective view about the appropriate stance of monetary policy by focusing on trade in that particular security, thereby determining the rate to be calibrated daily by officials. In effect, all domestic interest rates would then be market-determined.

\section{The Exchange Rate}

Questions may arise as to where the exchange rate fits into this proposal, since, in addition to interest rates, the exchange rate is taken into account by (for example) the Canadian and New Zealand central banks when assessing monetary conditions.

\footnotetext{
5 Kajjakis and Moschos (1995), Lee (1995) and Lowe (1992) focus on the usefulness of the yield curve as an indicator of economic conditions.
} 
However, under the prevailing floating exchange rate system, the central bank, by definition, should allow the exchange rate to find its own equilibrium level according to the play of demand and supply in the foreign-exchange market itself. Hence there is no explicit need to factor the exchange rate into the proposed interest-rate rule (though rule-based changes in cash rates relative to foreign interest rates may still influence exchange-rate movements and hence real activity, as suggested earlier in Figure 1).

\section{Inflation}

Where would such a rule leave the low-inflation objective of monetary policy? It is a fundamental axiom of monetary economics that central banks which ultimately have monopoly control over the issue of the domestic currency cannot simultaneously set interest rates and the money supply at pre-determined levels. Targeting the money supply for given money demand implies that the interest rate becomes endogenous, whereas targeting the interest rate for the same money demand implies that the money supply becomes endogenous. Hence the money supply must always adjust in response to the central bank's interest targeting activity.

Accordingly, if the central bank strictly adhered to the proposed interest-rate rule, then the money markets would also indirectly govern the rate of domestic money growth and so ultimately decide the rate of inflation over the longer term. This may suggest that the interest rate rule could lead to higher inflation. But such an outcome seems unlikely in view of the strong aversion to inflation that money and bond markets have demonstrated in the past. Financial markets now react quickly to news of higher inflation by immediately pushing up interest rates. Under the proposed rule, the financial sector itself would thereby automatically induce higher cash rates, and hence automatically check domestic money supply growth, which is the ultimate determinant of inflation.

\section{Conclusion}

The current practice of discretionary interest-rate setting by central banks is clearly a major cause of uncertainty in financial markets about the future course of short-term interest rates. The Reserve Bank of Australia's discretion in periodically changing cash rates is likely to explain part of the persistent, though time-varying, premium on Australia's long-term interest rates.

Of the several rules that have been proposed to replace central banks' discretion over interest rates, probably the best known is the money growth rule derived from the monetarist doctrine that growth of the money supply is the key determinant of inflation. Yet this rule, though aimed at nullifying the potentially debilitating effects of central bank discretion, presumed superior information on the part of the authorities to the extent that the stipulated money growth rule had to be premised on the central bank's forecasts of future economy-wide activity.

The alternative rule proposed here recognises that policy-makers are likely to know less about the behaviour of the economy at large than is known collectively by 
the financial sector, operating on behalf of resident households and firms transacting in domestic and international markets. Since interest rates of varying yields are proximately determined by the money and bond markets, it follows that the information held by these markets about economic fundamentals should be used as a basis for setting official interest rates. Financial markets would then effectively determine interest rates, consisitent with the way they set the value of the currency under a floating exchange rate regime.

\section{References}

Cox, J., J. Ingersoll \& S. Ross (1985), 'A Theory of the Term Structure of Interest Rates', Econometrica 53: 385-407.

Culbertson, J. (1957), 'The Term Structure of Interest Rates', Quarterly Journal of Economics 71: 485 517.

Fisher, I. (1896), 'Appreciation and Interest', Publications of the American Fconomic Association 11: 1100.

Fuhrer, J. (1996), 'Monetary Policy Shifts and Long Term Interest Rates', Quarterly Joumal of Economics 111: 1183-209.

Hicks, J. (1939), Value and Capital (2nd ed.), Oxford University Press, Oxford.

Karjakis, C. \& D. Moschos (1995), 'The Information Content of the Yield Curve in Australia', Journal of Macroeconomics 17: 93-109.

Lee, S. (1995), 'Macroeconomic Sources of Time Varying Risk Premia in the Term Stucture of Interest Rates', Journal of Money, Credit and Banking 27: 549-69.

Lowe, P. (1992), 'The Term Structure of Interest Rates, Real Activity and Inflation', Reserve Bank of Australia, Sydney (Discussion Paper No. 9204).

Malkiel, B. (1986), The Term Stucture of Intenest Rates, Princeton University Press, Princeton.

McFadyen, K., K. Pickerill \& M. Devaney (1991), "The Expectations Hypothesis of the Term Structure: More Evidence', Journal of Economics and Business 43: 79-85.

Melino, A. (1988), 'The Term Structure of Interest Rates: Evidence and Theory', Joumal of Economic Surveys 2: 335-66.

Roll, R. (1970), The Behaviour of Interest Rates, Basic Books, New York.

Stevens, G. (1996), 'Monetary Policy in Australia', Seminar for Teachers, Reserve Bank of Australia, Sydney.

Taylor, M. (1992), 'Modelling the Yield Curve', The Economic.Journal 102: 524-37.

Tease, W. (1988), 'The Expectations Theory of the Term Structure and Short Term Interest Rates in Australia', Economic Record 64: 120-7.

The author gratefully acknowledges the comments of two anonymous referees and the editor. 